
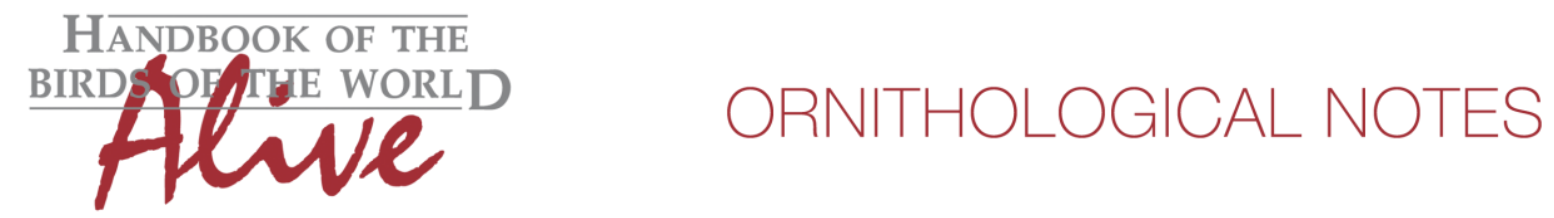

\title{
Notes on the vocalizations of Long-tailed Antbird (Drymophila caudata)
}

Peter Boesman

In the following we briefly analyze voice of the different races of Long-tailed Antbird (Drymophila caudata) and we try to quantify the extent of any vocal differences using the criteria proposed by Tobias et al. (2010), as a support for taxonomic review.

Voice has already been analyzed in detail (Isler et al. 2012). Vocal differences of 10 populations were assessed, but after re-grouping these 10 study groups into 4 proposed species, there is surprisingly no indication what are the remaining vocal differences between these newly-formed species, based on the shared vocal properties of every group.

We have tried to unravel this, only for male loudsongs (Fig. 1).

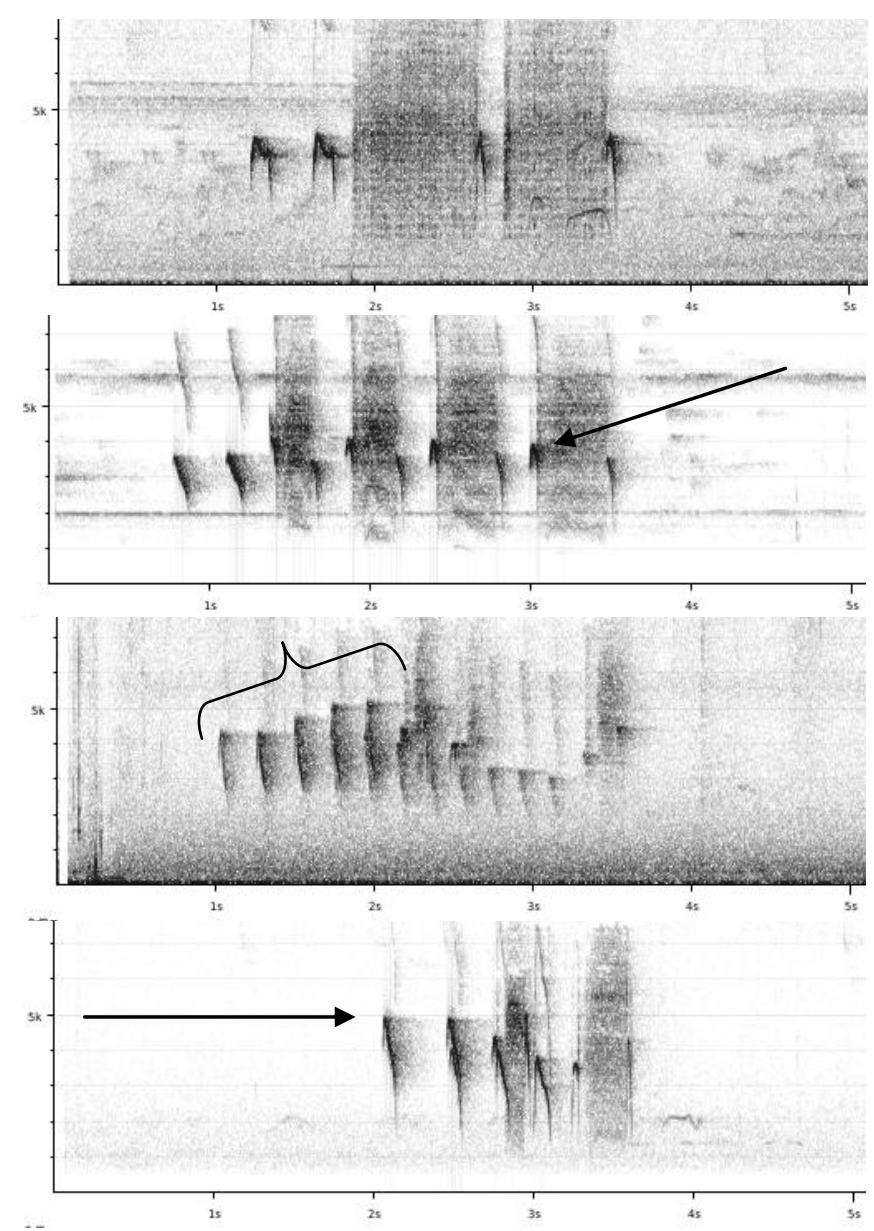

Figure 1: from top to bottom: typical example of male loudsong of group 1 ((klagesi/aristeguietana), group 2 (hellmayri), group 3 (caudata/upper Magdalena) and group 4 (striaticeps/occidentalis/peruvianus/boliviana). 

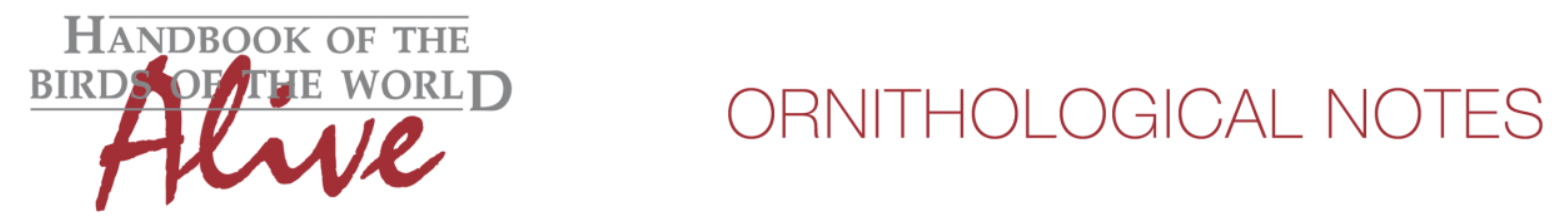

group 1 (klagesi/ aristeguietana) vs. group 2 (hellmayri)

Isler et al. mention only one vocal difference: the long raspy notes are preceded by a short over-slurred note in hellmayri and not in klagesi/ aristeguietana (a check of recordings on XC confirms this). This could be scored based on the parameter 'number of short notes', which then typically has a difference of 2, leading to a score of about 2-3.

group 3 (caudata/upper Magdalena)

Is unique in having a larger number of introductory notes (4-6) compared to all other taxa (typically 2, occasionally up to 4). Also, these notes rise in pitch, unlike all other taxa. These are fairly strong quantitative parameters, and could be scored at least 2 each.

group 4 (striaticeps/occidentalis/peruvianus/boliviana) vs. group 1 (klagesi/ aristeguietana) The former has a higher max. frequency of the two introductory notes. Appendix 3 on-line mentions $3599 \mathrm{~Hz} \pm 159$ vs. $4767 \mathrm{~Hz} \pm 296$ resulting in an effect size 4.9 -> score 2

Just as in hellmayri, the long raspy notes are preceded by a short over-slurred note, while not in klagesi/ aristeguietana. This could be scored based on the parameter 'number of short notes', which then typically has a difference of 2, leading to a score of about 2-3.

Furthermore, in the former the introductory notes are shorter in length. Appendix 3 on-line mentions $111 \pm 9$ vs striaticeps $91 \pm 9$ and others $69 \pm 9$, leading to an effect size larger than 2 , equivalent to a score 2 .

group 2 (hellmayri) vs. group 4 (striaticeps/occidentalis/peruvianus/boliviana) Isler et al. mention 2 differences: hellmayri has a lower max. frequency of the two introductory notes. Appendix 3 on-line mentions $3599 \mathrm{~Hz} \pm 159$ vs. $4767 \mathrm{~Hz} \pm 296$, resulting in an effect size 4.9 and a score 2 . hellmayri has also introductory notes longer in length.

Appendix 3 on-line mentions $111 \pm 9$ vs striaticeps $91 \pm 9$ and others $69 \pm 9$, leading to an effect size larger than 2, equivalent to a score 2

When comparing also female loudsongs and calls, the number of differences will increase. The Tobias criteria prescribes only to include the 2 largest differences of the most distinctive vocalization into the score. We reach following total scores for vocal difference based on male loudsong:

group 1 (klagesi/ aristeguietana) vs. group 2 (hellmayri): total score 2-3

group 1 (klagesi/aristeguietana) vs. group 4 (striaticeps/occidentalis/peruvianus/boliviana) total score 4-5

group 2 (hellmayri) vs. group 4 (striaticeps/occidentalis/peruvianus/boliviana): total score 4 group 3 (caudata/upper Magdalena) vs. all others: total score 4

We can thus conclude that the four groups are vocally distinct, and that more specifically male loudsongs are moderately different. 

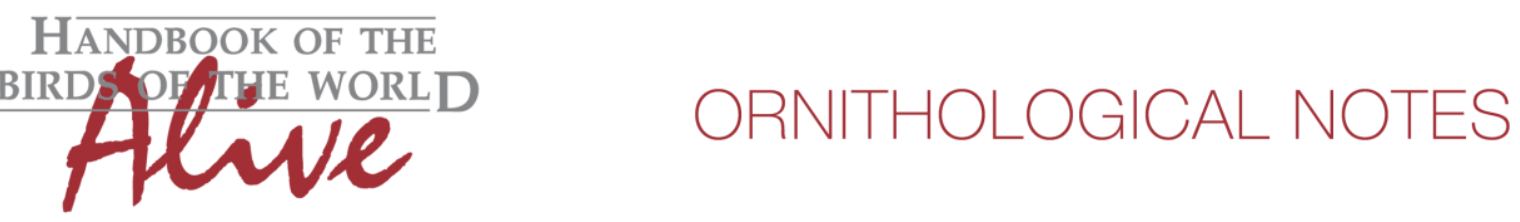

This note was finalized on 6th May 2015, using sound recordings available on-line at that moment. We would like to thank in particular the sound recordists who placed their recordings for this species on XC, from where the selected sonograms.

\section{References}

Isler, M. L., A. M. Cuervo, G. A. Bravo, \& R. T. Brumfield. 2012. An integrative approach to species-level systematics reveals the depth of diversification in an Andean thamnophilid, the Long-tailed Antbird. Condor 114: 571-583

Tobias, J.A., Seddon, N., Spottiswoode, C.N., Pilgrim, J.D., Fishpool, L.D.C. \& Collar, N.J. (2010). Quantitative criteria for species delimitation. Ibis 152(4): 724-746.

\section{Recommended citation}

Boesman, P. (2016). Notes on the vocalizations of Long-tailed Antbird (Drymophila caudata). HBW Alive Ornithological Note 58. In: Handbook of the Birds of the World Alive. Lynx Edicions, Barcelona. (retrieved from http://www.hbw.com/node/931938 on 4 May 2016). 